\title{
Granular institutional investors and global market interdependence ${ }^{i s}$
}

\author{
Yothin Jinjarak $^{\mathrm{a}, \mathrm{d}}$, Huanhuan Zheng ${ }^{\mathrm{b}, \mathrm{c}, *}$ \\ ${ }^{a}$ University of London, Financial and Management Studies, United Kingdom \\ ${ }^{\mathrm{b}}$ The University of York, Department of Economics and Related Studies, York, United Kingdom \\ ${ }^{\mathrm{c}}$ The Chinese University of Hong Kong, Institute of Global Economics and Finance, Hong Kong \\ ${ }^{\mathrm{d}}$ ADB Institute, Tokyo, Japan
}

JEL classification:

E44

F3

G15

\section{Keywords:}

Systemic risk

Risk propagation

Market interdependence

Financial crisis

\begin{abstract}
A B S T R A C T
We study the propagation of global investment risk across markets through the granular view of institutional investors. Applying the conditional value-at-risk estimation to micro-level weekly observations of international mutual funds between 2003 and 2011, we find that idiosyncratic shocks to large institutional investors explain both aggregate market risk and cross-market risk interdependence. Conditional on the US capital markets being in financial distress, idiosyncratic shocks to the top 10\% largest funds investing in the US explain about $40 \%$ of the risk fluctuations in other non-US markets. The findings are also economically and statistically significant for the top largest funds investing in nonUS markets, with the effects becoming especially large during the global financial crisis of 2007-09. These results are robust after controlling for common risk factors and applying alternative measures of idiosyncratic shocks.
\end{abstract}

(c) 2014 Elsevier Ltd. All rights reserved.

\section{Introduction}

The recent global financial crisis of 2007-2009 has highlighted exceptional magnitude of global interdependence across financial markets. The market linkages seem particularly pronounced when

\footnotetext{
is We are thankful for comments from Ciaran Driver, Sushanta Mallick, Christine Oughton, the 2012 Annual Conference of the Royal Economic Society, The Kiel Institute for the World Economy, SOAS, Queen Mary, University of London, University of York, and Peking University HSBC Business School. Huanhuan Zheng acknowledges financial support from the direct grant (2021106) of the Chinese University of Hong Kong.

* Corresponding author. The University of York, Department of Economics and Related Studies, York, United Kingdom.

E-mail addresses: yj5@soas.ac.uk (Y. Jinjarak), Huanhuan.zheng@york.ac.uk, arwenzh@gmail.com (H. Zheng).
} 
financial shocks hit head on large financial institutions. On the date of Lehman Brothers bankruptcy, the S\&P 500 lost $4.7 \%$ of its value, and the market tumble immediately spread to most major financial markets, with the MSCI world index dropped by $3.6 \%$ on that day. Yet, while there is garden-variety anecdotal evidence about the role of idiosyncratic shocks to large financial institutions, empirical studies on how they account for the global financial market interdependence remain scarce and largely inconclusive.

Built upon the granular view of Gabaix (2011) and the CoVaR (conditional value-at-risk) methodology of Adrian and Brunnermeier (2011), this paper sheds new light on the association between idiosyncratic shocks to large financial institutions, 'the granular institutional investors', and global market interdependence as well as market aggregate risk. Gabaix's granular view suggests that the idiosyncratic micro-level shocks are not cancelled out at the aggregate level; instead, they have the potential to generate nontrivial aggregate shocks, and via general equilibrium, all market players.

“... many economic fluctuations are not, primitively, due to small diffuse shocks that directly affect every firm. Instead, many economic fluctuations are attributable to the incompressible "grains" of economic activity, the large firms. ... call this view the "granular" hypothesis. In the granular view, idiosyncratic shocks to large firms have the potential to generate nontrivial aggregate shocks that affect GDP, and via general equilibrium, all firms."

(Gabaix, 2011: 734-735).

Gabaix finds that a third of variations in the US output growth is dependent significantly on the performance of the largest 100 firms, thereby providing some smoking-gun evidence of this granular hypothesis. Through the lens of this granular view transposed onto the financial market, we are interested in whether idiosyncratic shocks to large financial institutions provide information on the aggregate market risk and the cross-market risk interdependence. If the granular view holds broadly in the financial market, we expect the micro-level shocks to explain an important fraction of the overall market risk fluctuations. Moreover, as the idiosyncratic shocks to big institutions could generate not only nontrivial aggregate shocks in a single market but also additional impacts on other institutions across borders, we also expect the shocks to contribute to the variations in the global market risk comovements.

As the granular view motivates our study with respect to the role of idiosyncratic shocks to large financial institutions, the CoVaR methodology provides a foundation to estimate the cross market interdependence in a simple and efficient way for the objective of our empirical exercise. Adrian and Brunnermeier (2011) apply CoVaR to measure the systemic risk contribution of individual financial institutions. Several studies extend this CoVaR method and its related versions to investigate different aspects of interdependence in the financial market. ${ }^{1}$ We contribute to this strand of literature and apply $\mathrm{CoVaR}$, essentially the value at risk of one financial market conditional on another financial market being in distress, to measure the magnitude of global market interdependence. The CoVaR measure incorporates the risk driven by the market-specific characteristics, risk transmitted from another market as well common factors that affect all financial markets alike. This empirical approach enables us to estimate the aggregate market interdependence efficiently and is especially useful in accounting for potential channels through which the idiosyncratic shocks may influence the global market interdependence. $^{2}$

Using a weekly micro-level dataset on international mutual funds, we find that an economically significant fraction of the cross-market risk interdependence is explained by the idiosyncratic shocks to large institutional investors. In particular, idiosyncratic shocks to the top 10\% largest funds investing in the US account for about $40 \%$ of the variations in the non-US market's risk conditional on the US being in distress. Our results suggest that $13 \%$ of the variance of global market interdependence can be

\footnotetext{
1 See Engle and Manganelli (2004), Adams et al. (2010), Wong and Fong (2011), and Gauthier et al. (2010).

2 It is true that we may apply CoVaR to calculate the aggregate market risk conditional on a big financial institution being in trouble to gauge the importance of the institution. However, such a CoVaR measure cannot differentiate whether the risk transmitted from a specific financial institution originates from its idiosyncratic shock or common factors that affect both the financial institution and the whole market. That is why we complement it with the granular approach by Gabaix (2011).
} 
explained by common factors. The granular residuals, a measure of the idiosyncratic shocks to large institutional investors, increase the explanatory power to $28 \%$. Further, the granular residuals account for $20 \%$ of the fluctuations in the aggregate market risk. These results suggest that useful information can be extracted from examining the idiosyncratic shocks to large institutional investors.

This paper is related to two strands of literature. The first is about the systematic importance of individual financial institution. Adrian and Brunnermeier (2011) document that bigger institutions post greater risk on the financial system using a sample of commercial banks, broker dealers, insurance companies, and real estate companies in the US. Similar evidence is found in the context of international mutual funds by Jinjarak and Zheng (2012) and in the banking sector of Asia and the Pacific by Huang et al. (2012). López-Espinosa et al. (2012), in contrast, find little relevance in the relationship between bank size and systemic risk. However, none of these studies differentiate whether the risk transmitted from a specific financial institution originates from its idiosyncratic shocks or common factors that affect that financial institution and the whole market. The granular residual of Gabaix (2011) differentiates the idiosyncratic shocks to large institutions. In the context of financial markets, the granular residuals can be used to test the granular hypothesis whether idiosyncratic shocks to large financial institution have any impact on the aggregate fluctuations. Existing empirical studies test the granular hypothesis within country; for example, Giovanni and Levchenko (2011) find evidence in support of the granular hypothesis for trade in each of the 50 largest economies in the world; Blank et al. (2009) provide similar evidence in the German banking system; and Buch and Neugebauer (2011) document that in 35 European countries, idiosyncratic shocks to loan growth at large banks have a significant short-run impact on GDP growth. Our paper tests the granular hypothesis in a broader financial market context and tries to establish the relationship between the idiosyncratic shocks to granular institutional investors and the global market interdependence.

Theoretically, the granular view holds as long as the size of the institutional investors follows a power law distribution with an exponent close to -1 (Gabaix, 2011). Idiosyncratic shocks that cannot be averaged out at country level may spill over to the regional/global market as long as the condition on size distribution holds. Nonetheless the idiosyncratic shocks to large institutional investors in one market, even trivial ones at the global aggregate, may affect the cross-market interdependence: they could change the dynamic interaction between two related markets through their impact on aggregate risk fluctuations of the market they invest in, and the shocks may cause other investors to update their information and investment styles, which in turn transmit the shocks to other institutions, even if they have no direct linkage to the institutions facing initial shocks (Giesecke, 2004; Collin-Dufresne et al., 2010).

The second strand of literature is on the international market interdependence via equity investment, the institutional investors' role in financial intermediation and the transmission mechanism of liquidity shocks throughout the global capital markets. The premise of this literature is the competitive interaction among investors worldwide and its associated market inefficiency that potentially leads to externalities and spillovers in the financial markets (Stein, 2009). Given the market inefficiency, the distress of one market may inadvertently depress the others. Jotikasthira et al. (2012) find in a sample of international mutual funds that funding-driven fire sales of mutual funds domiciled in developed markets significantly affect their asset holdings in emerging markets, thereby increasing the sensitivity of overall emerging-market returns to developed-market returns. Raddatz and Schmukler (2012) document that country exposures of mutual funds change procyclically: investment weights are reduced in countries faced with financial crisis and increased in countries with improved conditions. This active portfolio rebalancing during the crisis helps propagate shocks across markets. ${ }^{3}$ Our empirical framework identifies an additional of global market interdependence based on the CoVaR measure, complementing earlier works, i.e. Forbes and Rigobon (2002), Longin and Solnik (2001), Bekaert et al. (2012), on explaining the cross-border correlation of portfolio investments.

\footnotetext{
3 See also Broner et al. (2006), Calvo and Mendoza (2000), Claessens and Forbes (2001), Froot et al. (2001), Gelos (2011) and Jinjarak et al. (2011).
} 


\section{Methodology and data}

\subsection{Static measures of conditional risk}

Let $R_{i}$ be the investment return variable of region $i$, and $\mathrm{VaR}_{i}$ be the $1 \%$ Value at Risk (VaR) that measures the tail risk of investment in region $i$. The risk of investment in region $j$ conditional on region $i$ being in market distress is denoted as $\operatorname{CoVaR}_{j \mid i}$, for $j \neq i$. To estimate $\operatorname{CoVaR}_{j \mid i}$, we follow Adrian and Brunnermeier (2011) by estimating a $1 \%$ quantile regression of region $j$ 's return $R_{j}$ on region $i$ 's return $R_{i}$ :

$$
R_{j, t}=\alpha_{j \mid i}+\beta_{j \mid i} R_{i, t}+e_{j \mid i, t} .
$$

When region $i$ is in distress, we have $R_{i}=-\mathrm{VaR}_{i}$, where $-\mathrm{VaR}_{i}$ is the $1 \%$ quantile of $R_{i}$, which measures the unconditional risk of region $i$. Unlike the OLS method that estimates the coefficients by minimizing the sum of the squared residuals, the $1 \%$ quantile regression finds the solution by minimizing the sum of the absolute residuals in the following equation (Koenker and Bassett, 1978):

$$
\min _{\alpha_{j i}, \beta_{j j i}}\left[\sum_{t \in\left\{t \mid R_{j, t} \geq \alpha_{j \mid i}+\beta_{j \mid i} R_{i, t}\right\}} 1 \%\left|R_{j, t}-\alpha_{j \mid i}-\beta_{j \mid i} R_{i, t}\right|+\sum_{t \in\left\{t \mid R_{j, t}<\alpha_{j \mid i}+\beta_{j \mid i} R_{i, t}\right\}} 99 \%\left|R_{j, t}-\alpha_{j \mid i}-\beta_{j \mid i} R_{i, t}\right|\right] .
$$

Note that in the quantile regression, the coefficients estimated from the regression of $R_{j, t}$ on $R_{i, t}$ is different from those based on the regression of $R_{i, t}$ on $R_{j, t}$. This property enables us to document any asymmetric interdependence for each pair of region $(i, j)$.

To capture the risk linkage between regions $j$ and $i$, we apply the conditional risk measure $\mathrm{CoVaR}_{j \mid i}$, where a negative value of the conditional risk $\mathrm{CoVaR}_{j \mid i}$ equals the fitted value of the following $1 \%$ quantile regression conditional on $R_{i}=-\mathrm{VaR}_{i}$ :

$$
-\operatorname{CoVaR}_{j \mid i}=\widehat{\alpha}_{j \mid i}-\widehat{\beta}_{j \mid i} \operatorname{VaR}_{i}, \operatorname{CoVaR}_{j \mid i}>\operatorname{VaR}_{j},
$$

where $\widehat{\alpha}_{j \mid i}$ and $\widehat{\beta}_{j \mid i}$ are coefficients estimated from Eq. (1). Higher value of $\operatorname{CoVaR}_{j \mid i}$ suggests higher investment risk of region $j$ conditional on region $i$ being in market distress. If $\operatorname{CoVaR}_{j \mid i}>\operatorname{VaR}_{j}$, the conditional risk of region $j$ is higher than the unconditional risk, suggesting accordingly that the investment risk of region $i$ increases the risk of region $j$.

\subsection{Time-varying measures of conditional risk}

While static CoVaR is efficient in summarizing the overall market interdependence, they ignore the dynamics of these conditional risk measures. To capture the time variations in the joint distribution of multiple returns, i.e $R_{i}$ and $R_{j}$, we follow Adrian and Brunnermeier (2011) by estimating the conditional distribution as a function of a vector of lagged state variables $M_{t-1}$ :

$$
\begin{aligned}
& R_{i, t}=\alpha_{i}+\gamma_{i} M_{t-1}+\varepsilon_{i}, \\
& R_{j, t}=\alpha_{j \mid i}+\beta_{j \mid i} R_{i, t}+\gamma_{j \mid i} M_{t-1}+\varepsilon_{j \mid i},
\end{aligned}
$$

where $M_{t-1}$ includes the simple return of the MSCI World Index ( $\left.R_{\text {MSCI_Global }}\right)$, the gap between the 3month and overnight London Interbank Offered Rate or LIBOR (LIBOR $3 \mathrm{~m}-\mathrm{o} / \mathrm{n}$ ), the difference between the overnight LIBOR and the federal funds target rate $\left(\mathrm{LIBOR}_{\mathrm{o} / \mathrm{n}}-\mathrm{FFTarget}\right)$, the difference between the Chicago Board of Trade's (CBOT) federal funds futures rate and the 3-month treasury rate (FFFutures - Tbill $_{3 \mathrm{~m}}$ ), the difference between the federal funds Futures rate and federal funds target rate (FFTarget - FFFutures), and the return of the Chicago Board Options Exchange Volatility Index $\left(R_{\mathrm{VIX}}\right){ }^{4}$

\footnotetext{
${ }^{4}$ See Hamilton (2008) and Bernanke and Kenneth (2005) for the rationales of these state variables.
} 
From a $1 \%$ quantile regression of Eq. (2), we obtain the time-varying unconditional risk measure as $\mathrm{VaR}_{i, t}=-\left(\widehat{\alpha}_{i}+\widehat{\gamma}_{i} M_{t-1}\right)$. Based on a $1 \%$ quantile regression of Eq. (3), we calculate the time-varying conditional risk as

$$
\operatorname{CoVaR}_{j, t \mid i, t}=-\left[\widehat{\alpha}_{j \mid i}+\widehat{\beta}_{j \mid i}\left(-\mathrm{VaR}_{i, t}\right)+\widehat{\gamma}_{j \mid i} M_{t-1}\right] .
$$

The conditional risk $\mathrm{CoVaR}_{j, t \mid i, t}$ can be decomposed into three components: region $j$ 's specific risk $\left(-\widehat{\alpha}_{j \mid i}\right)$, the risk originated from region $i\left(\widehat{\beta}_{j \mid i} \mathrm{VaR}_{i, t}\right)$ and the risk driven by common factors $\left(-\widehat{\gamma}_{j \mid i} M_{t-1}\right)^{5}$

To measure the degree to which the market distress of region $i$ contributes to the risk in region $j$, we apply the risk contribution measure $\Delta \operatorname{CoVaR}_{j, t \mid i, t}$, which is defined as the difference in the region $j$ 's risk conditional on region $i$ being in distress $\left(R_{i, t}=-\mathrm{VaR}_{i, t}\right)$, and conditional on region $i$ being normal $\left(R_{i, t}=-\mathrm{VaR}_{i, t}^{50 \%}\right)$ :

$$
\Delta \operatorname{CoVaR}_{j, t \mid i, t}=\widehat{\beta}_{j \mid i}\left(\operatorname{VaR}_{i, t}-\operatorname{VaR}_{i, t}^{50 \%}\right) \text {, }
$$

where $-\mathrm{VaR}_{i, t}^{50 \%}$ is calculated as the fitted value from $50 \%$ quantile regression of Eq. (2). This way $\Delta \mathrm{CoVaR}_{j, t \mid i, t}$ captures the risk contribution of region $i$ to region $j$ or region $j$ 's risk exposure to region $i$ at period $t$.

This approach can be directly applied to the regional aggregate return as well as to fund return. To calculate the time-varying VaR for each equity fund, we replace the regional return in Eq. (2) with the fund's return and estimate the quantile regressions. Then, to calculate the risk contribution of fund $k$ to the region $j$, we replace the return of region $i$ on the right hand side of Eq. (3) with the return of fund $k$ accordingly.

\subsection{Data}

Our analysis uses weekly fund-level data from Emerging Portfolio Fund Research (EPFR), which reports total net assets (TNAs) under management and returns on net asset value (NAV). The aggregate market return for each region is calculated as the TNA-weighted NAV return of all funds investing in that region. The sample covers equity funds investing in both developed and emerging markets from November 23, 2003, to June 8, 2011 (395 weeks). The data are screened using standard procedures following Coval and Stafford (2007) and Jotikasthira et al. (2012): First, excluding funds with TNA less than USD 5 million throughout the sample period; second, dropping funds with flows or returns falling out of the range $[-50 \%, 200 \%]^{6}$; and third, keeping funds with more than 30 weeks of observations. The final sample includes 1,409,861 fund-weeks, covering 10,303 equity funds investing in the global markets. The 10,303 funds are classified into 9 regional markets based on the fund's geographic investment focus. The four categories that represent emerging markets are Asia ex-Japan (Asia henceforth); Europe, the Middle East and Africa (EMEA); Latin America (LatAm); and the Global Emerging Market (GEM). ${ }^{7}$ The other five categories represent developed markets are Japan; Pacific; the US; Western Europe (WE); and the global developed market (Globe). ${ }^{8}$ While GEM and Globe overlap each other geographically, the equity funds identified in these two regions are not the same. In the sample, the number of funds investing in their respective market for every week is greater than 30 . The weekly average observations in each market range from 59 to 793. The data used to construct state variables (MSCI world index, 3-month and overnight LIBOR, federal fund target rate, CBOT's federal funds futures rate, and VIX) are obtained from Datastream and Bloomberg.

\footnotetext{
5 See Wong and Fong (2011).

${ }^{6}$ This step excludes newly-established funds whose data are relatively noisy. This step however drops a very small fraction of total observations.

7 This classification follows from EPFR, the mutual fund data provider. Funds in the GEM and Globe categories target the broad emerging market and developed market respectively.

${ }^{8}$ See Appendix Table 1 for country lists under each category.
} 


\section{Conditional risk and market interdependence}

The static risk measure of conditional risk is reported in Fig. 1. The heatmap plots this measure of market interdependence with the estimated static CoVaR in the off-diagonal cells and the VaR in the diagonal cells, using a darker colour for higher risk. Specifically, for any $j \neq i$, the value reported in row $j$ and column $i$ is $\operatorname{CoVaR}_{j \mid i}$, the static risk of region $j$ conditional on region $i$ being in market distress, where $j$ and $i$ correspond to regions in $S=$ \{Asia, EMEA, LatAm, GEM, Japan, Pacific, US, WE, Globe\}. Additionally, each diagonal cell reports the unconditional risk $\mathrm{VaR}_{j}$, where $j$ is the region specified in the leftmost column. Note that the values in the diagonal cells are consistently smaller than any other cells in the same row - this implies that the unconditional risk $\left(\mathrm{VaR}_{j}\right)$ of region $j$ is smaller than the risk of this region conditional on the other region being in market distress $\left(\operatorname{CoVaR}_{j \mid i}\right)$ for any $i \in S$ and $i \neq j$. The plots therefore tentatively suggest market interdependence across regions.

To compare developed and emerging markets, it is worth pointing out that the cells in the first four rows showing the conditional and unconditional risks of the four emerging markets are generally darker than the other rows that represent the risk of developed markets. It suggests that emerging markets are generally riskier than developed markets. Further, the risk of an emerging market, say $j$, conditional on a developed market, say $i$, being in distress $\left(\mathrm{CoVaR}_{j \mid i}\right)$ is typically higher than the risk of a developed market conditional on an emerging market being in distress $\left(\mathrm{CoVaR}_{i \mid j}\right)$. This however does not mean that the response of emerging market to the risk from developed market is more sensitive than the response of developed market to the risk from emerging market: CoVaR measures the level of the conditional risk but not the marginal risk generated from the other market.

To account for the risk dynamics over time, we present the time-varying unconditional and conditional risk measures. Shown in Table 1, the evidence on the market interdependence is quite robust after accounting for the time-varying risk dynamics: the average conditional risk of a market (calculated as $\left.\sum_{t=1}^{T} \sum_{i \neq j}^{i \in S} \operatorname{CoVaR}_{j, t \mid i, t} /(8 T)\right)$ is found to be consistently higher than its average unconditional risk $\left(\sum_{t=1}^{T} \mathrm{VaR}_{j, t} / T\right)$ throughout the sample period for all of the nine markets.

Having documented the pairwise market interdependence among these markets, we next report the risk exposure and risk contribution in the last two rows of Table 1. The average risk exposure of

\begin{tabular}{|c|c|c|c|c|c|c|c|c|c|}
\hline & A sia & EMEA & LatAm & GEM & Japan & Pacific & US & WE & Globe \\
\hline Asia & 9.31 & 13.32 & 10.83 & 11.03 & 12.49 & 12.68 & 11.99 & 11.53 & 10.78 \\
\hline EMEA & 16.18 & 12.54 & 15.19 & 14.99 & 16.96 & 15.57 & 15.52 & 16.28 & 13.02 \\
\hline LatAm & 18.07 & 20.35 & 11.13 & 17.83 & 19.80 & 17.37 & 17.98 & 21.20 & 15.67 \\
\hline GEM & 14.16 & 13.18 & 11.66 & 10.21 & 12.65 & 11.87 & 12.08 & 14.88 & 13.13 \\
\hline Japan & 11.49 & 11.76 & 10.69 & 10.77 & 7.16 & 11.52 & 10.51 & 11.94 & 9.34 \\
\hline Pacific & 12.19 & 11.81 & 11.22 & 11.88 & 9.07 & 7.14 & 10.25 & 11.21 & 9.57 \\
\hline US & 11.97 & 11.18 & 10.00 & 10.73 & 10.39 & 10.16 & 7.04 & 10.86 & 8.00 \\
\hline$W E$ & 11.11 & 9.71 & 10.28 & 9.96 & 8.33 & 9.96 & 7.54 & 6.94 & 7.19 \\
\hline Globe & 10.88 & 10.34 & 9.22 & 9.97 & 9.44 & 8.76 & 9.68 & 9.40 & 6.02 \\
\hline
\end{tabular}

Fig. 1. Market interdependence based on static unconditional and conditional risk. The diagonal cells of the heatmap illustrate the VaR of Asia ex-Japan (Asia); Europe, the Middle East and Africa (EMEA); Latin America (LatAm); the Global Emerging Market (GEM); Japan; Pacific; the US; Western Europe (WE); and the global developed market (Globe). The off-diagonal cells report the CoVaR of markets specified on the very left column conditional on the market specified on the top row being in distress. 
Table 1

Summary statistics on unconditional and conditional risk. This table reports the average regional aggregate return $R_{j, t}$ and unconditional risk $\mathrm{VaR}_{j, t}$ for each region $j$ specified in the top row. The average risk of market $j$ conditional on any of the other region $i$ being in distress is calculated as the average of market $j$ 's conditional risks $\sum_{t=1}^{T} \sum_{i \neq j}^{i \in S} \operatorname{CoVaR}_{j, t \mid i, t} /(8 T)$. The average risk exposure and risk contribution of region $j$ is calculated as $\sum_{t=1}^{T} \sum_{i \neq j}^{i \in S} \Delta \operatorname{CoVaR}_{j, t \mid i, t} /(8 T)$ and $\sum_{t=1}^{T} \sum_{i \neq j}^{i \in S} \Delta \operatorname{CoVaR}_{i, t \mid j, t} /(8 T)$ respectively. Standard errors are reported in parenthesis below the average statistics. All numbers are reported in percentage.

\begin{tabular}{llllllllll}
\hline & Asia & EMEA & LatAm & GEM & Japan & Pacific & US & WE & Globe \\
\hline$R_{j, t}$ & 0.33 & 0.37 & 0.54 & 0.24 & 0.02 & 0.14 & 0.13 & 0.14 & 0.18 \\
& $(3.16)$ & $(3.74)$ & $(4.16)$ & $(3.16)$ & $(2.76)$ & $(2.83)$ & $(2.46)$ & $(2.29)$ & $(2.47)$ \\
$\mathrm{VaR}_{j, t}$ & 5.65 & 9.06 & 9.46 & 6.83 & 6.66 & 5.33 & 4.81 & 5.16 & 5.67 \\
& $(2.83)$ & $(3.60)$ & $(2.49)$ & $(3.50)$ & $(1.54)$ & $(2.26)$ & $(1.90)$ & $(1.80)$ & $(1.34)$ \\
$\mathrm{CoVaR}_{j, t \mid i, t}$ & 9.21 & 11.41 & 12.64 & 8.91 & 11.20 & 8.34 & 6.85 & 7.87 & 7.36 \\
& $(3.46)$ & $(3.74)$ & $(4.27)$ & $(3.14)$ & $(2.99)$ & $(2.94)$ & $(2.18)$ & $(2.87)$ & $(2.47)$ \\
Risk exposure & 5.81 & 6.99 & 7.71 & 5.93 & 6.41 & 5.74 & 3.75 & 5.00 & 5.00 \\
& $(1.96)$ & $(2.45)$ & $(2.91)$ & $(2.00)$ & $(2.14)$ & $(2.15)$ & $(1.60)$ & $(2.08)$ & $(1.89)$ \\
Risk contribution & 5.58 & 6.46 & 5.77 & 6.95 & 4.48 & 5.65 & 5.51 & 5.40 & 6.56 \\
& $(2.74)$ & $(2.75)$ & $(1.96)$ & $(3.10)$ & $(1.96)$ & $(2.38)$ & $(2.17)$ & $(1.71)$ & $(1.67)$ \\
\hline
\end{tabular}

Notes on abbreviation: Asia: Asia ex-Japan; EMEA: Europe, the Middle East and Africa; LatAm: Latin America; GEM: the global emerging market; WE: Western Europe; Globe: the global developed market.

market $j$ to the risk in other market, measured by $\sum_{t=1}^{T} \sum_{i \neq j}^{i \in S} \Delta \operatorname{CoVaR}_{j, t \mid i, t} /(8 T)$, ranges from $3.75 \%$ $(j=\mathrm{US})$ to $7.71 \%(j=$ LatAm). The average risk exposure of US is the lowest while that of LatAm is the highest suggesting that US is the least sensitive to the overall risk of the other markets while LatAm is the most sensitive. The average risk contribution of market $j$ to the other market, measured by $\sum_{t=1}^{T} \sum_{i \neq j}^{i \in S} \Delta \mathrm{CoVaR}_{i, t j, t} /(8 T)$, varies from $4.48 \%(j=$ Japan $)$ to $6.95 \%(j=\mathrm{GEM})$ : this suggests that, on average, the risk contribution of Japan is the most influential to the rest of the global markets while the risk contribution of GEM is the least influential. Note that the market that is more sensitive to the external risk is not necessarily the market that has higher risk contribution. We observe that, for each of the emerging markets, its average risk exposure to the other markets is typically larger than its corresponding risk contribution to the other markets; for the developed markets, however, the average risk exposure to the other markets is generally weaker than their corresponding risk contribution.

To gain further insight into the conditional risk measure, we decompose for each region $j$ its average conditional risk $\mathrm{CoVaR}_{j, t \mid i, t}$ into three components: the risk driven by common factors that affect all markets, the region-specific risk and the spillover risk contributed by the other markets (see Eq. (4)). The average proportion of $\mathrm{CoVaR}_{j, t \mid i, t}$ attributed to each source is presented in Fig. 2 . The spillover risk accounts for more than $50 \%$ of the average conditional risk. The proportion of conditional risk

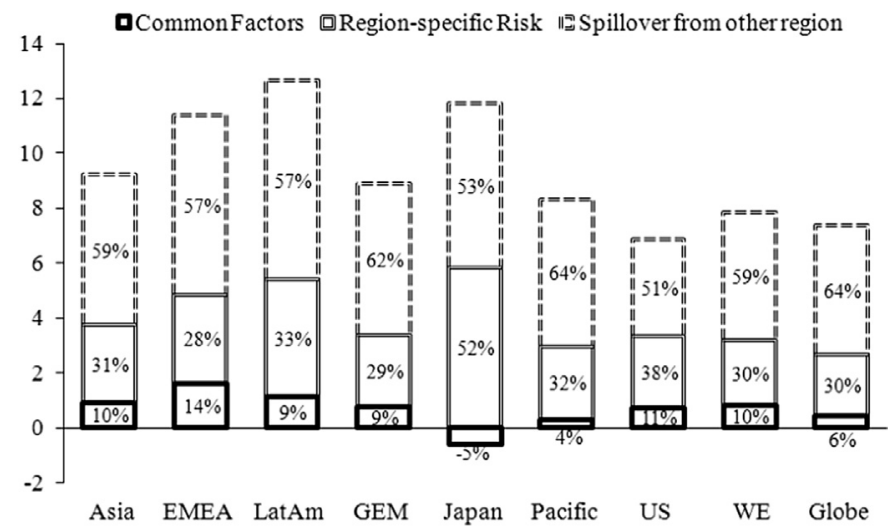

Fig. 2. Components of CoVaR. 
attributed to region-specific characters is small in EMEA (28\%) and large in US (38\%). The common factors appear to be the least important: the proportion of the conditional risk driven by common factors ranges from $-5 \%$ in Japan to $14 \%$ in EMEA.

\section{Granular origins}

We have so far documented some evidence of market interdependence across markets. In this section, we delve into the origins of market interdependence by looking at the micro characteristics of equity funds. Given the large number of funds investing in the global market, according to the rule of diversification, an idiosyncratic (fund-specific) shock should have insignificant effect on the aggregate market risk. However, this may not be the case for a market with a fat-tailed distribution of funds. In a different analysis, Gabaix shows that a third of variations in the US output growth is explained by the output shock to the largest 100 firms. In our paper, we are interested in the application of the granular hypothesis in the global equity investment. Specifically, we test whether idiosyncratic shocks to large funds have any economically significant effect on the aggregate risk. If the granular view is applicable, the idiosyncratic shocks could potentially contribute to the global market risk co-movements. Moreover, given the presence of global market interdependence documented in the previous section, the idiosyncratic shocks to large funds in region $j$ could contribute to the conditional risk of the other region $i$ accordingly.

We start the exploration into the granular hypothesis by checking whether the equity fund size follows the power-law distribution. Fig. 3 plots the cumulative distribution of the average TNA and aggregate volatility of large funds in our sample. Interestingly we find that the size of largest funds (top $10 \%$ ) and the aggregate volatility obey the power-law distribution, with the exponent coefficient approximately equals to -1 and -3 . Shown in Table 2 , the $10 \%$ largest funds account for $48-67 \%$ of TNA across markets.

\subsection{Definition of granular residuals}

To test the granular hypothesis, we sort equity funds in each market in ascending order according to their TNA and examine the top 10\% largest funds. For each large fund $k$ investing in market $i$, we calculate $\operatorname{Var}_{i, t}^{k}$, its unconditional risk at period $t$, based on Eq. (2). The average unconditional risk of these funds investing in market $i$ at period $t$ is measured by

$$
\overline{\mathrm{VaR}}_{i, t}=\sum_{k=1}^{K_{i, t}} \mathrm{VaR}_{i, t} / K_{i, t},
$$

where $K_{i, t}$ is the number of funds in the top size quintile in market $i$ at period $t$. The granular residuals of market $i$ at period $t, \Gamma_{i, t}$, which is a measure of the idiosyncratic shocks to large funds in market $i$, is
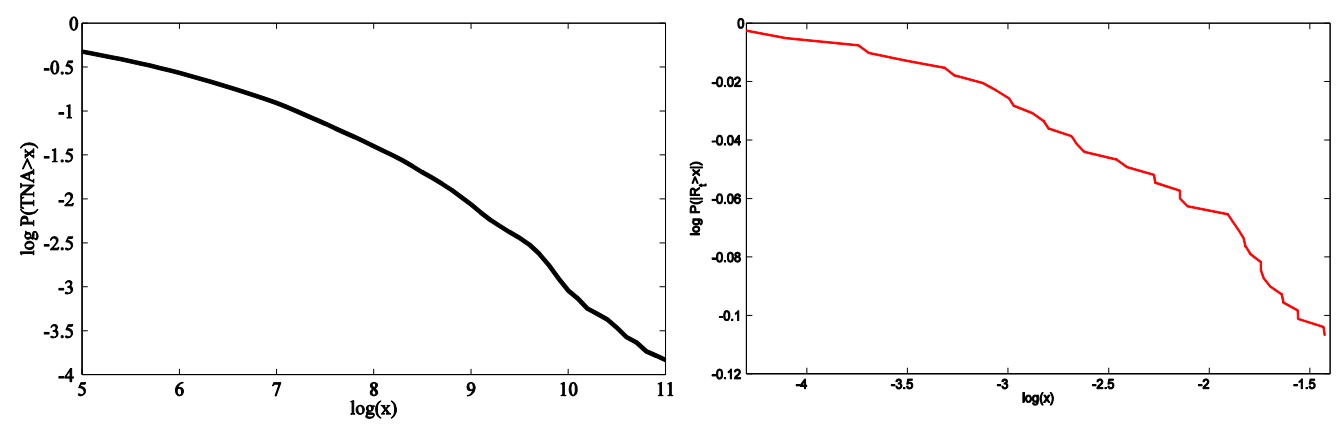

Fig. 3. Cumulative distribution of the total net assets under management and the absolute value of the aggregate return of the top $10 \%$ largest funds in our sample. 
Table 2

Size of the top $10 \%$ largest funds. This table reports the time-series average statistics and their standard deviations (s.d) for (i) $\mathrm{TNA}_{i, t}$, the total net asset (TNA) under management (in million USD) for each regional market $i$ specified in the top row; (ii) $\sum_{k=1}^{K_{i, t}} \mathrm{TNA}_{i, t-1}^{k}$, the TNA managed by the top $10 \%$ largest funds in market $i$, where $K_{i, t}$ is the number of the top $10 \%$ largest funds in market $i$ at period $t$ and TNA $A_{i, t-1}^{k}$ is the TNA of fund $k$ investing in market $i$ at period $t$; (iii) $\sum_{k=1}^{K_{i, t}} \mathrm{TNA}_{i, t-1}^{k} / \mathrm{TNA}_{i, t}$, the ratio of the TNA managed by the top $10 \%$ largest funds to the TNA of the whole market; (iv) $\sum_{k=1}^{K_{i, t}} \mathrm{TNA}_{i, t-1}^{k} / K_{i, t}$ the average TNA of the top $10 \%$ largest funds in market $i$; and (v) $N_{i, t}$, the total number of funds in market $i$.

\begin{tabular}{llllllllll}
\hline & Asia & EMEA & LatAm & GEM & Japan & Pacific & US & WE & Globe \\
\hline $\mathrm{TNA}_{i, t}$ & 119,024 & 32,398 & 27,729 & 163,621 & 40,133 & 16,289 & $1,204,877$ & 219,990 & 484,008 \\
s.d & 69,339 & 15,138 & 18,980 & 91,725 & 15,662 & 6450 & 435,065 & 101,719 & 191,816 \\
$\sum_{k=1}^{K_{i, t}} \mathrm{TNA}_{i, t-1}^{k}$ & 69,578 & 15,668 & 14,580 & 102,946 & 23,418 & 8148 & 731,398 & 120,204 & 319,592 \\
$\mathrm{s.d}$ & 44,601 & 7609 & 11,373 & 59,745 & 8785 & 3043 & 269,669 & 56,353 & 120,510 \\
$\sum_{k=1}^{K_{i, t}} \mathrm{TNA}_{i, t-1}^{k} / \mathrm{TNA}_{i, t}$ & 0.558 & 0.481 & 0.477 & 0.636 & 0.587 & 0.517 & 0.606 & 0.545 & 0.669 \\
$\mathrm{s.d}$ & 0.056 & 0.033 & 0.090 & 0.051 & 0.031 & 0.074 & 0.024 & 0.024 & 0.029 \\
$\sum_{k=1}^{K_{i, t}} \mathrm{TNA}_{i, t-1}^{k} / K_{i, t}$ & 2117 & 1420 & 2404 & 5607 & 1634 & 1650 & 5426 & 1963 & 4572 \\
$\mathrm{s.d}$ & 919 & 702 & 1366 & 1970 & 781 & 462 & 1635 & 724 & 1638 \\
$N_{i, t}$ & 307 & 123 & 58 & 181 & 155 & 55 & 1375 & 609 & 731 \\
$\mathrm{s.d}$ & 101 & 49 & 23 & 55 & 28 & 16 & 323 & 198 & 212 \\
\hline
\end{tabular}

calculated as the TNA-weighted sum of the difference between fund-specific unconditional risk $\operatorname{Var}_{i, t}^{k}$ and the average unconditional risk of large funds $\overline{\mathrm{VaR}}_{i, t}$ :

$$
\Gamma_{i, t}=\sum_{k=1}^{K_{i, t}} \frac{\mathrm{TNA}_{i, t-1}^{k}}{\mathrm{TNA}_{i, t-1}}\left(\mathrm{VaR}_{i, t}^{k}-\overline{\mathrm{VaR}}_{i, t}\right),
$$

where TNA $A_{i, t-1}^{k}$ is the TNA of fund $k$ that belongs to the top $10 \%$ largest funds in market $i$ at period $t-1$, and $\mathrm{TNA}_{i, t-1}$ is the aggregate TNA of all funds investing in market $i$ at period $t-1$. The granular residual is essentially the sum of idiosyncratic shocks to large funds (measured by the standard deviation of their unconditional risk), weighted by size. This application is derived from Gabaix (2011).

Firstly, we are interested in what fraction of the total variance of market aggregate risk can be explained by the granular residual. If diversification is at work, we expect the idiosyncratic shocks to disappear at the aggregate level. To put this in perspective, consider a market with 10,000 funds of identical size and identical standard deviation $\sigma$. Then the standard deviation of the market is $\sigma / 100$. If there is a $10 \%$ idiosyncratic shock to a single fund, the cumulative effect of such a shock on the market is $0.1 \%$, which is insignificant. However, in a world with large granular institutional investors, we expect a nontrivial fraction of the aggregate market risk to be explained the granular residuals. Yet, plausibly the risk of large funds could be influenced by the common aggregate market shock, i.e. reverse causality, a possibility that we deal with using several robustness checks afterwards. Secondly, based on the estimates of granular residuals, we are also interested in the market interdependence and the influence of large institutional investors on market externality in the global equity markets.

\subsection{Explanatory power of granular residuals}

\subsubsection{Common risk factors and granular residuals}

By and large, common risks are understood to be important factors driving the global market interdependence. To further examine the potential effects of granular residuals, we empirically measure their explanatory power on the global market interdependence together with the common risk factors in the equity fund data.

We focus on three proxies of common risk factors widely monitored in the markets: the change of investment sentiment (as measured by the return of VIX); the shock to market liquidity (as measured by the return of the TED spread), the difference between the three-month LIBOR and the three-month US T-bill interest rate; and the change of the global market environment (as measured by the return of the MSCI World Index). 
Regress VaR and CoVaR on the vector $X_{t}$ that consists of the three common factors:

$$
\begin{aligned}
& \operatorname{VaR}_{i, t}=C_{i}+A_{i} X_{t}+e_{i}, \\
& \operatorname{CoVaR}_{j, t \mid i, t}=C_{j \mid i}+A_{j \mid i} X_{t}+e_{j \mid i},
\end{aligned}
$$

we estimate the explanatory power of these common risk factors on the aggregate market risk and the global market interdependence. The left panel of Fig. 4 reports the adjusted $R^{2}$ from the regression of $\mathrm{VaR}_{i, t}$ in the diagonal cell of column $i$ and the adjusted $R^{2}$ from the regression of $\mathrm{CoVaR}_{j, t \mid i, t}$ in the cell at column $i$ row $j(j \neq i)$.

To examine the granular residuals, we estimate regressions of VaR and CoVaR on the granular residuals and $X_{t}$ :

$$
\begin{aligned}
& \operatorname{VaR}_{i, t}=C_{i}+A_{i} X_{t}+\lambda_{i} \Gamma_{i, t}+e_{i}, \\
& \operatorname{CoVaR}_{j, t \mid i, t}=C_{j \mid i}+A_{j \mid i} X_{t}+\lambda_{j \mid i} \Gamma_{i, t}+e_{j \mid i},
\end{aligned}
$$

The right panel of Fig. 4 reports in the diagonal cells the adjusted $R^{2}$ from the regressions of VaR and in the off-diagonal cells the adjusted $R^{2}$ from the regressions of CoVaR.

Comparing the two heatmaps in Fig. 4, we observe that most adjusted $R^{2}$ in the right panel is higher than the values in the left panel, emphasized darker shade on the right heatmap. On average, the common risk factors explain $12 \%$ of the unconditional aggregate market risk measured by VaR and $13 \%$ of the global market interdependence measured by CoVaR. The explanatory power has increased more than double to $27 \%$ and $28 \%$ respectively with the granular residuals. In the following, we investigate further into the effects of granular residuals as a new and influential source of fluctuation in the aggregate risk and the global market interdependence.

\subsubsection{Granular origins of aggregate market risk}

To estimate the effects of granular residuals on the aggregate market risk, we regress VaR on the granular residuals, accounting for idiosyncratic shocks to the largest $10 \%$ funds in each region:

$$
\mathrm{VaR}_{i, t}=C_{i}+\lambda_{i} \Gamma_{i, t}+e_{i}
$$

The estimation results are reported in Panel A of Table 3. The coefficients of the granular residuals are statistically significant and positive across all markets (except for GEM and Pacific). This means a $1 \%$ increase of the granular residuals adds to the VaR of the US, Asia, EMEA, Globe, WE, LatAm and Japan by $26 \%, 11 \%, 9 \%, 4 \%, 3 \%, 3 \%$ and $2 \%$ respectively. The granular residuals explain a nontrivial amount of the

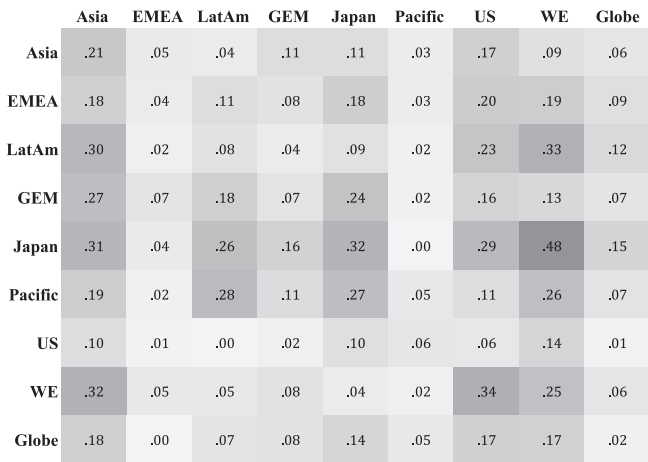

(a) Common Factors

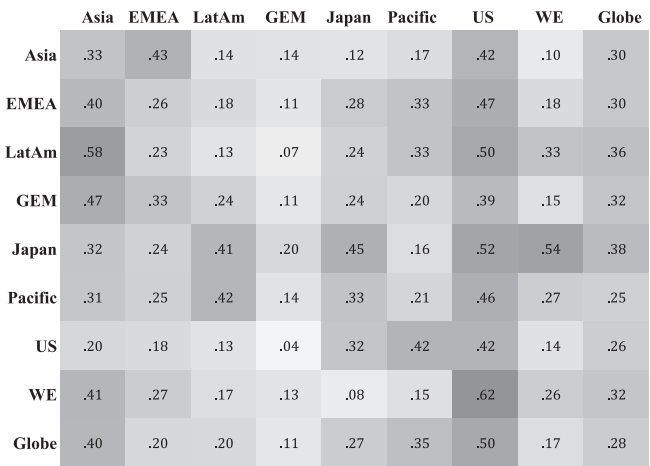

(b) Common factors and granular residuals

Fig. 4. The adjusted $R^{2}$ with and without granular residuals. In the left panel, the diagonal cells report the adjusted $R^{2}$ from the regressions of VaR (of the market specified in the leftmost column) on three common factors, while the off-diagonal cells report the adjusted $R^{2}$ in the regressions of CoVaR (risk of the market specified in the leftmost column conditional on the market in the top row being in distress) on three common factors. The right panel records the adjusted $R^{2}$ from the regressions of VaR and CoVaR on common factors and granular residuals. 
Table 3

Explanatory power of the granular residuals. Panel A reports the estimation results from the regression of $\mathrm{VaR}_{i, t}=C_{i}+\lambda_{i} \Gamma_{i, t}+e_{i}$, for each market $i$ specified in the first row. Panel B summarizes the average response of the conditional risk of the market specified in the first row to the granular residuals based on regressions of $\operatorname{CoVaR}_{j, t \mid i, t}=C_{j \mid i}+\lambda_{j \mid i} T_{i, t}+e_{j \mid i}$. For each market $j$ specified in the first row of panel B, the average coefficient of $\Gamma_{i, t}$ is calculated as $\sum_{i \neq j}^{i \in S} \widehat{\lambda}_{j \mid i} / 8$. The $t$-statistics reported in the parenthesis is calculated as the simple average of the $t$-statistics of the eight estimations. The other reported average statistics is calculated in the same way. Panel $C$ reports the average impact of the granular residuals of the market specified in the first row on the other market's conditional risk based on regressions of $\mathrm{CoVaR}_{i, t \mid j, t}=C_{i \mid j}+\lambda_{i \mid j} \Gamma_{j, t}+e_{i \mid j}$. For each market $j$ specified in the first row of panel C, the average coefficient of $\Gamma_{j, t}$ is calculated as $\sum_{i \neq j}^{i \in S} \widehat{\lambda}_{i j j} / 8$. The other statistics presented are calculated in the same way.

\begin{tabular}{|c|c|c|c|c|c|c|c|c|c|}
\hline & Asia & EMEA & LatAm & GEM & Japan & Pacific & US & WE & Globe \\
\hline \multicolumn{10}{|c|}{ Panel A: Dependent variable $=V a R_{i, t}$} \\
\hline$\Gamma_{i, t}$ & $\begin{array}{l}11.237^{* * *} \\
(10.990)\end{array}$ & $\begin{array}{l}8.964 * * * \\
(10.889)\end{array}$ & $\begin{array}{l}2.886^{* * *} \\
(5.035)\end{array}$ & $\begin{array}{l}-1.314^{* * *} \\
(-2.752)\end{array}$ & $\begin{array}{l}2.479 * * * \\
(14.947)\end{array}$ & $\begin{array}{l}-4.031^{* * *} \\
(-7.729)\end{array}$ & $\begin{array}{l}25.898^{* * * *} \\
(16.889)\end{array}$ & $\begin{array}{l}3.339 * * * \\
(3.197)\end{array}$ & $\begin{array}{l}3.731^{* * *} \\
(11.863)\end{array}$ \\
\hline Constant & $\begin{array}{l}4.269 * * * \\
(24.136)\end{array}$ & $\begin{array}{l}8.077^{* * *} \\
(44.099)\end{array}$ & $\begin{array}{l}9.039^{* * *} \\
(60.869)\end{array}$ & $\begin{array}{l}6.996^{* * *} \\
(36.979)\end{array}$ & $\begin{array}{l}6.503^{* * *} \\
(103.404)\end{array}$ & $\begin{array}{l}5.794^{* * *} \\
(51.219)\end{array}$ & $\begin{array}{l}5.272^{* * *} \\
(67.698)\end{array}$ & $\begin{array}{l}5.152^{* * *} \\
(57.588)\end{array}$ & $\begin{array}{l}5.785^{* * *} \\
(98.769)\end{array}$ \\
\hline$N$ & 395 & 394 & 394 & 366 & 394 & 310 & 395 & 395 & 395 \\
\hline$R^{2}$ & 0.235 & 0.232 & 0.061 & 0.020 & 0.363 & 0.162 & 0.421 & 0.025 & 0.264 \\
\hline Adj. $R^{2}$ & 0.233 & 0.230 & 0.0583 & 0.0177 & 0.361 & 0.160 & 0.419 & 0.0229 & 0.262 \\
\hline \multicolumn{10}{|c|}{ Panel B: Dependent Variable $=\operatorname{CoVaR}_{j, t \mid i, t}$} \\
\hline$\Gamma_{i, t}$ & $\begin{array}{l}9.227^{* * *} \\
(4.514)\end{array}$ & $\begin{array}{l}9.580^{* * * *} \\
(4.211)\end{array}$ & $\begin{array}{l}11.867^{* * *} \\
(7.073)\end{array}$ & $\begin{array}{l}10.077^{* * *} \\
(6.208)\end{array}$ & $\begin{array}{l}9.171^{* * *} \\
(4.024)\end{array}$ & $\begin{array}{l}9.215^{* * *} \\
(6.478)\end{array}$ & $\begin{array}{l}2.019 * * \\
(2.403)\end{array}$ & $\begin{array}{l}8.593 * * * \\
(5.610)\end{array}$ & $\begin{array}{l}6.393^{* * * *} \\
(5.482)\end{array}$ \\
\hline Constant & $\begin{array}{l}9.180^{* * *} \\
(46.561)\end{array}$ & $\begin{array}{l}11.169 * * * \\
(49.819)\end{array}$ & $\begin{array}{l}12.261^{* * * *} \\
(67.363)\end{array}$ & $\begin{array}{l}8.563^{* * *} \\
(46.083)\end{array}$ & $\begin{array}{l}11.187^{* * *} \\
(56.193)\end{array}$ & $\begin{array}{l}8.111^{* * *} \\
(47.338)\end{array}$ & $\begin{array}{l}6.660^{* * * *} \\
(48.327)\end{array}$ & $\begin{array}{l}8.381^{* * * *} \\
(57.782)\end{array}$ & $\begin{array}{l}7.883^{* * *} \\
(61.233)\end{array}$ \\
\hline$N$ & 380 & 381 & 381 & 384 & 381 & 391 & 380 & 380 & 380 \\
\hline$R^{2}$ & 0.177 & 0.208 & 0.245 & 0.213 & 0.189 & 0.199 & 0.177 & 0.206 & 0.249 \\
\hline Adj. $R^{2}$ & 0.175 & 0.206 & 0.243 & 0.211 & 0.187 & 0.197 & 0.175 & 0.203 & 0.247 \\
\hline \multicolumn{10}{|c|}{ Panel C: Dependent Variable $=\operatorname{CoVaR}_{i, t \mid j, t}$} \\
\hline$\Gamma_{j, t}$ & $\begin{array}{l}14.330^{\text {*** }} \\
(12.325)\end{array}$ & $\begin{array}{l}7.775^{* * *} \\
(11.515)\end{array}$ & $\begin{array}{l}4.153^{* * *} \\
(8.118)\end{array}$ & $\begin{array}{l}-1.057^{*} \\
(-2.035)\end{array}$ & $\begin{array}{l}2.607^{* * *} \\
(9.406)\end{array}$ & $\begin{array}{l}-6.425^{* * *} \\
(-9.902)\end{array}$ & $\begin{array}{l}42.445^{\text {**** }} \\
(16.112)\end{array}$ & $\begin{array}{l}3.438^{* *} \\
(2.436)\end{array}$ & $\begin{array}{l}7.992^{* * *} \\
(12.819)\end{array}$ \\
\hline Constant & $\begin{array}{l}7.371^{* * * *} \\
(41.688)\end{array}$ & $\begin{array}{l}9.388^{* * *} \\
(62.421)\end{array}$ & $\begin{array}{l}8.438^{* * *} \\
(64.170)\end{array}$ & $\begin{array}{l}9.907^{* * *} \\
(50.126)\end{array}$ & $\begin{array}{l}8.995^{* * *} \\
(86.050)\end{array}$ & $\begin{array}{l}9.208^{* * *} \\
(65.411)\end{array}$ & $\begin{array}{l}10.092^{\text {**** }} \\
(74.917)\end{array}$ & $\begin{array}{l}8.681^{* * *} \\
(59.415)\end{array}$ & $\begin{array}{l}9.715^{* * *} \\
(84.384)\end{array}$ \\
\hline$N$ & 395 & 394 & 394 & 366 & 394 & 310 & 395 & 395 & 395 \\
\hline$R^{2}$ & 0.278 & 0.252 & 0.145 & 0.012 & 0.189 & 0.242 & 0.397 & 0.020 & 0.295 \\
\hline Adj. $R^{2}$ & 0.276 & 0.250 & 0.143 & 0.009 & 0.187 & 0.239 & 0.395 & 0.018 & 0.293 \\
\hline
\end{tabular}

Notes: *significant at $10 \%$; ${ }^{* *}$ significant at $5 \%$; ${ }^{* * *}$ significant at $1 \%$.

variations in unconditional aggregate market risk VaR, the adjusted $R^{2}$ is the highest in the US at $42 \%$. Additional lags of the granular residuals in the estimation increase the $R^{2}$ even further. ${ }^{9}$ Our equity funds data lend supportive evidence that idiosyncratic shocks to large funds significantly influence the aggregate market risk fluctuations, in addition to the common risk factors.

\subsubsection{Granular origins of market interdependence}

Next we study the explanatory power of the granular residuals on the market interdependence. For each market $j$, we run a regression of $\mathrm{CoVaR}_{j, t \mid i, t}$, market $j$ 's risk conditional on market $i(j \neq i)$ being in distress, on the granular residuals of market $i$ :

$$
\operatorname{CoVaR}_{j, t \mid i, t}=C_{j \mid i}+\lambda_{j \mid i} \Gamma_{i, t}+e_{j \mid i} .
$$

We find that the coefficient of $\Gamma_{i, t}$ is generally positive and significant. To summarize the response of one market's conditional risk to the granular residuals of the other market, for each market $j$, we report estimation results by taking the average statistics from the eight regressions of $\mathrm{CoVaR}_{j, t \mid i, t}$, where $i$ is

\footnotetext{
${ }^{9}$ These results are not reported due to space constraint but available upon request.
} 


\begin{tabular}{|c|c|c|c|c|c|c|c|c|c|}
\hline & Asia & EMEA & LatAm & GEM & Japan & Pacific & US & WE & Globe \\
\hline Asia & 11.24 & 11.38 & 5.25 & -.99 & 1.58 & -5.10 & 46.95 & 4.00 & 10.75 \\
\hline EMEA & 23.19 & 8.96 & 4.72 & -1.52 & 3.74 & -9.18 & 45.24 & 1.39 & 9.05 \\
\hline LatAm & 29.28 & 9.13 & 2.89 & -1.43 & 4.90 & -10.02 & 51.69 & 2.31 & 9.08 \\
\hline GEM & 21.29 & 8.65 & 3.70 & -1.31 & 1.82 & -5.63 & 37.24 & 6.16 & 7.38 \\
\hline Japan & 5.12 & 6.52 & 4.33 & -.92 & 2.48 & -5.47 & 47.03 & 8.67 & 8.09 \\
\hline Pacific & 9.07 & 8.46 & 4.73 & -.69 & 2.04 & -4.03 & 40.31 & 3.14 & 6.67 \\
\hline US & 6.41 & 4.99 & 3.27 & -.39 & 3.04 & -6.36 & 25.90 & -.37 & 5.55 \\
\hline WE & 8.47 & 7.57 & 4.32 & -1.58 & 1.22 & -3.55 & 41.60 & 3.34 & 7.36 \\
\hline Globe & 11.81 & 5.51 & 2.91 & -.94 & 2.52 & -6.09 & 29.49 & 2.20 & 3.73 \\
\hline
\end{tabular}

Fig. 5. Coefficients of the granular residuals. The diagonal cells report the coefficient of the granular residual in the regressions of VaR (of the market specified in the most left column) based on Eq. (5) while the off-diagonal cells report similar statistics in the regressions of CoVaR (risk of the market specified in the leftmost column conditional on the market in the top row being in distress) based on Eq. (6).

one of the markets other than $j$. For example, the average coefficient of the granular residual in the regression of $\mathrm{CoVaR}_{j, t \mid i, t}$ is calculated as $\sum_{i \neq j}^{i \in S} \widehat{\lambda}_{j \mid i} / 8$. As shown in Panel B of Table 3, we find supportive evidence that market-specific granular residuals have significant impact on the other market's conditional risk. Specifically, the conditional risk of LatAm is augmented by $12 \%$ on average if the granular residuals of other markets increase by $1 \%$, the most sensitive response among the nine markets. The US appears to be the least responsive to the granular residuals of the other markets - a $1 \%$ increase in the granular residuals of a non-US market adds only $2 \%$ to the risk of US conditional on the other markets being in distress.

To evaluate the average impact of one market's granular residuals on the other market's conditional risk, Panel $\mathrm{C}$ of Table 3 summarizes the estimation results from another dimension. Specifically, it reports the average coefficient of $\Gamma_{j, t}$, as $\sum_{i \neq j}^{i \in S} \widehat{\lambda}_{i j} / 8$, based on the eight regressions of $\operatorname{CoVaR}_{i, t j j, t}$ on $\Gamma_{j, t}$ for $j \neq i$. The results in Panel C of Table 3 show that, on average, the granular residuals of the US is most influential on the other market's conditional risk. For example, a $1 \%$ increase in the granular residual of the US adds about $42 \%$ to the risk of the other market conditional on US being in distress. In general, we find that a market's granular residuals increase the other market's conditional risk. ${ }^{10}$ Combining these results with the size information for the top largest $10 \%$ funds presented in Table 2 , there is no evidence that the impact of idiosyncratic shocks to the granular institutional investors increases with the average size or the proportion of the TNA under management.

\subsubsection{A closer look at granular origins}

In Fig. 5, we report in row $j$, column $i$ the coefficient of the granular residual in the regression of $\mathrm{CoVaR}_{j, t \mid i, t}$ on $\Gamma_{i, t}$, for any $j \neq i$ (see Eq. (6)). In the diagonal cells, we report the coefficient of the granular residual from the regression of $\mathrm{VaR}_{i, t}$ on $\Gamma_{i, t}$. (see Eq. (5)). Hence, row $j$ reflects the sensitivity of market $j$ 's risk to the granular residuals, while column $i$ describes the impact of market $i$ 's granular residuals on the market risk. The decomposition of granular residuals is incorporated into a heatmap of $9 \times 9$ matrix, with darker colour corresponding to higher coefficient of the granular residuals.

\footnotetext{
10 The granular residuals of GEM and Pacific are found to mitigate the conditional risk of the other markets on average. This may be driven by the rebalancing characteristics of funds investing in GEM and Pacific, which tend to attract more flows and generate relative good performance during recent financial crisis when investors are seeking safe heaven.
} 


\begin{tabular}{|c|c|c|c|c|c|c|c|c|c|}
\hline & Asia & EMEA & LatAm & GEM & Japan & Pacific & US & WE & Globe \\
\hline Asia & .23 & .42 & .12 & .00 & .07 & .13 & .35 & .01 & .30 \\
\hline EMEA & .34 & .23 & .10 & .01 & .23 & .29 & .38 & .00 & .29 \\
\hline LatAm & .47 & . 19 & .06 & .01 & .24 & .31 & .40 & .00 & .33 \\
\hline GEM & .36 & .30 & .09 & .02 & .09 & .18 & .33 & .02 & .32 \\
\hline Japan & .07 & .23 & .22 & .01 & .36 & .16 & .38 & .08 & .35 \\
\hline Pacific & .23 & .25 & .20 & .00 & .23 & .16 & .44 & .01 & .22 \\
\hline US & .17 & .18 & .12 & .00 & .30 & .39 & .42 & .00 & .23 \\
\hline WE & .22 & .25 & .13 & .02 & .07 & .13 & .45 & .02 & .32 \\
\hline Globe & .35 & .18 & .16 & .01 & .26 & .31 & .44 & .00 & .26 \\
\hline
\end{tabular}

Fig. 6. The adjusted $R^{2}$. The diagonal cells report the adjusted $R^{2}$ from the regressions of VaR (of the market specified in the most left column) based on Eq. (5), while the off-diagonal cells report similar statistics in the regressions of CoVaR (risk of the market specified in the leftmost column conditional on the market in the top row being in distress) based on Eq. (6).

According to Fig. 5, we find no evidence that any market is markedly more sensitive to the granular residuals (no a single row is dominantly darker than the others). Yet the conditional risk of Asia appears more responsive to the granular residuals of EMEA, LatAm and Globe; while the conditional risk of LatAm responds more to the granular residuals of Asia, Japan and US: i.e. if the granular residuals of Asia, Japan and US increase by $1 \%$ respectively, the conditional risk of LatAm increases by $29 \%, 10 \%$ and $52 \%$ respectively.

We also find that the granular residuals of US are the most influential, not only on its own aggregate risk, but also on the conditional risk of other markets. A 1\% increase in the granular residuals of the US is associated with $29 \%$ increment in the risk of Globe conditional on US being in distress. Conditional risks across all other regions respond even more significantly to the granular residuals of the US over the sample period of our study. Evidently, the granular residuals due to the investment of large institutional investors explain a nontrivial part of the fluctuations of both aggregate market risk and market interdependence.

We next look at the adjusted $R^{2}$ from regressions (5) and (6). For any $j \neq i$, the off-diagonal cell in row $j$ and column $i$ reports the adjusted $R^{2}$ from the regression of $\mathrm{CoVaR}_{j, t \mid i, t}$ on $\Gamma_{i, t}$ (Eq. (6)), while the diagonal cell in row $i$ and column $i$ records the adjusted $R^{2}$ from the regression of $\mathrm{VaR}_{i, t}$ on $\Gamma_{i, t}$ (Eq. (5)). These results are reported as a heatmap of $9 \times 9$ matrix in Fig. 6. The conditional risk of Asia is explained by the granular residuals of EMEA with an adjusted $R^{2}$ of $42 \%$, and that the conditional risks of both LatAm and GEM are explained by the granular residuals of Asia, with the adjusted $R^{2}$ being $47 \%$ and 36\% respectively. For all the other markets, their conditional risks are best explained by the granular residuals of US. In addition, the granular residuals of GEM and WE have low explanatory power on conditional risks of the other market, with the adjusted $R^{2}$ below $5 \%$. If the explanatory power of $\Gamma_{i, t}$ on $\mathrm{CoVaR}_{j, t i, t}$ is driven by market interdependence, we would expect the adjusted $R^{2}$ in row $j$ and column $i$ to be equal to the diagonal cell in column $i$ for any for any $j \neq i$. Our results are inconsistent with this possibility. ${ }^{11}$

\footnotetext{
11 Further, we noted that the granular residuals of LatAm explain about $6 \%$ of the variation in its own unconditional aggregate risk but $22 \%$ of Japan's risk conditional on LatAm being in distress (see column 'LatAm' in Fig. 6). In this case, the explanatory power of the granular residuals of LatAm on the conditional risk of Japan goes beyond the market interdependence. We also noted that the granular residuals of Japan explain 36\% of Japan's aggregate market risk, which is higher than any adjusted $R^{2}$ of the same column. It suggests that the explanatory power of the granular residuals of Japan on the conditional risk of the other market is operated through its market interdependence, but might potentially be offset by other factors.
} 


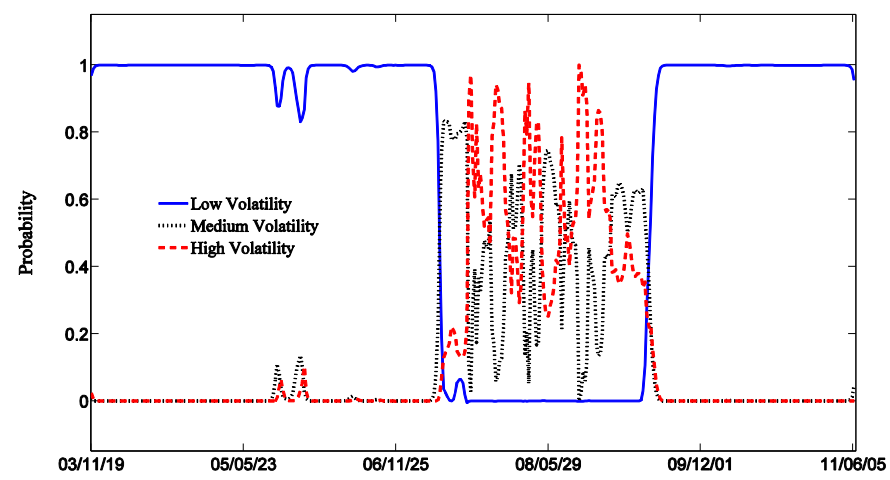

Fig. 7. Smooth transition probabilities of global market liquidity based on the TED spread. The TED spread is calculated as the difference between the three-month LIBOR and the three-month US T-bill interest rate.

\subsection{Robustness checks}

\subsubsection{Crisis versus noncrisis}

To test whether the granular origins of market interdependence varies over time, we split the sample into noncrisis and crisis subsamples, based on the volatility of the global market liquidity measured by the weekly TED spread (the difference between the three-month LIBOR and the threemonth US T-bill interest rate). Specifically, we estimate a 3-state (low, medium and high volatility) 2nd-order Markov-switching ARCH model on the weekly TED spread, following Hamilton and Susmel (1994). Fig. 7 plots the smoothed conditional probabilities whether week $t$ was in a low-volatility state (solid line), medium-volatility state (dotted line) or high-volatility state (dashed line). It shows that the market liquidity fell in the low-volatility state from 19 November 2003 to 25 April 2007, alternated between the medium- and high-volatility states from 2 May 2007 to 3 June 2009, and return to the low-volatility state afterwards. Based on the transition probabilities, we mark the medium- and high-volatility states as the crisis period: 2 May 2007 to 3 June 2009; and the other as the noncrisis period.

For each market, we re-estimate Eqs. (5) and (6) using subsamples of noncrisis and crisis periods respectively, and report the adjusted $R^{2}$ in Fig. 8. Generally, cells in the heatmap of the crisis period are darker than the corresponding cells for the noncrisis period, reflecting higher values of adjusted $R^{2}$ for the crisis subsample. The finding suggests that the explanatory power of granular residuals is higher in the crisis period than in the noncrisis period. This is especially the case for the granular residuals in the US: i.e. the granular residuals of US explains $3 \%$ of Asia's market risk conditional on US being in distress in the noncrisis period, but $56 \%$ in the crisis period.

Next, to see how the granular origins of market interdependence interact with the global financial crisis, we regress the conditional risk measures on the granular residuals, as well as an interaction term

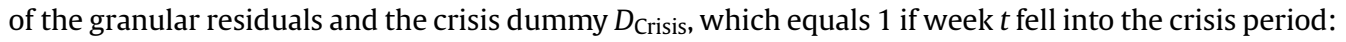

$$
\operatorname{CoVaR}_{j, t \mid i, t}=C_{j \mid i}+C_{j \mid i}^{\prime} D_{\text {Crisis }}+\lambda_{j \mid i} \Gamma_{i, t}+\lambda_{j \mid i}^{\prime} \Gamma_{i, t} D_{\text {Crisis }}+e_{j \mid i}
$$

Table 4 reports the average estimation results based on market $j$ 's risk conditional on the other markets being in distress. The coefficients of the granular residuals appear to be insignificant across the nine markets while the coefficients of the interaction term are generally positive and significant. It suggests that the conditional risks of these markets are not highly responsive to the granular residuals during noncrisis period but become much more sensitive in the crisis period.

Decomposing the coefficients of the interaction term into a matrix of $9 \times 9$, as shown in Fig. 9, we find that the association is mainly driven by the heightened sensitivity of the conditional risk across markets to the granular residuals of the US during the financial crisis. Following $1 \%$ increase of the granular residuals in the US, the risk of Japan conditional on US being in distress in the crisis period 


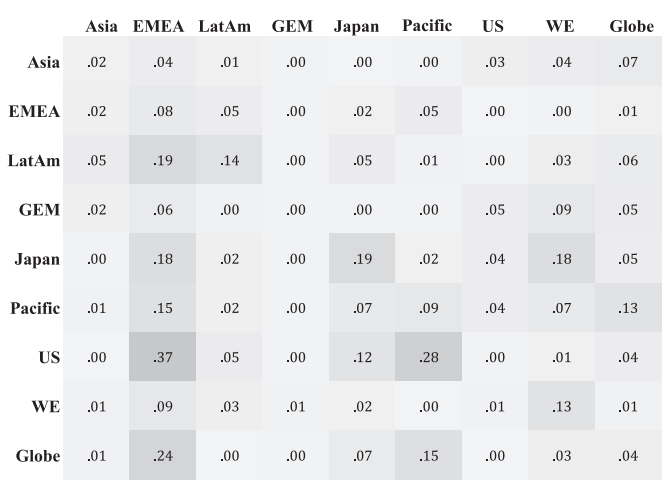

Noncrisis period

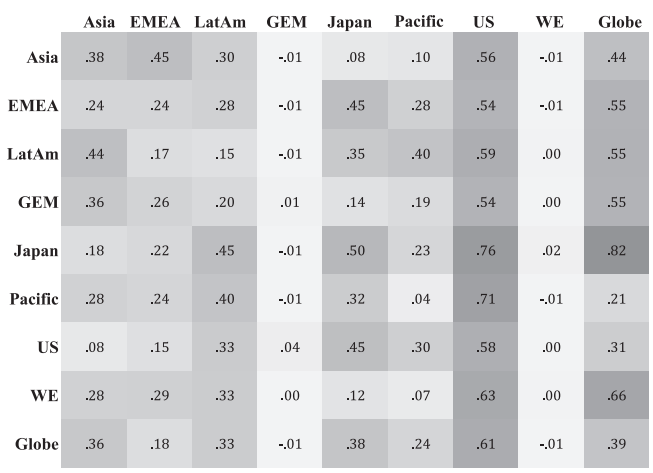

Crisis period

Fig. 8. The adjusted $R^{2}$ in noncrisis and crisis period. In the left panel, the diagonal cells report the adjusted $R^{2}$ from the regressions of VaR (of the market specified in the leftmost column) based on Eq. (5) using noncrisis subsample, while the off-diagonal cells report similar statistics in the regressions of $\mathrm{CoVaR}$ (risk of the market specified in the leftmost column conditional on the market in the top row being in distress) based on Eq. (6) using noncrisis subsample. The right panel reports the same statistics using the crisis subsample.

increases by $79 \%$ more than it does in the noncrisis period. The conditional risk also becomes more responsive to the granular residuals of Asia, EMEA, LatAm, Japan and Globe during the crisis.

\subsubsection{Alternative measure of the granular residuals}

We recalculate the granular residual using the 10 largest funds instead of the top 10\% largest funds in each market. Repeating the regressions of (5) and (6) using the crisis subsample, we find the values of adjusted $R^{2}$ remain robust as illustrated in Fig. 10.

\subsection{Predictive power of the granular residual}

Lastly, we study the predictive power of the granular residuals on the aggregate market risk and the global market interdependence. To proceed, we run regressions of $\mathrm{VaR}_{i, t}$ and $\mathrm{CoVaR}_{j, t \mid i, t}$ on the granular residuals:

$$
\mathrm{VaR}_{i, t}=C_{i}+\lambda_{i, 1} \Gamma_{i, t-1}+\lambda_{i, 2} \Gamma_{i, t-2}+e_{i}
$$

\section{Table 4}

The role of the granular residuals in noncrisis and crisis periods. For each market $j$ specified in the top row, this table reports the average estimated coefficients and their standard error from the regression of $\mathrm{CoVaR}_{j, t \mid i, t}=C_{j \mid i}+C_{j \mid i}^{\prime} D_{\text {Crisis }}+\lambda_{j \mid i} \Gamma_{i, t}+\lambda_{j \mid i}^{\prime} \Gamma_{i, t} D_{\text {Crisis }}+e_{j \mid i}$, for any and $i \neq j$. The average coefficient of the granular residuals $\Gamma_{i, t}$ is calculated as $\sum_{i \in S}^{i \in S} \widehat{\lambda}_{j \mid i} / 8$, while that of the interaction term $\Gamma_{i, t} D_{\text {Crisis }}$ and the crisis dummy $D_{\text {Crisis }}$ are calculated as $\sum_{i \neq j}^{i \in S} \widehat{\lambda}_{j \mid i}^{\prime} / 8$ and $\sum_{i \neq j}^{i \in S} \widehat{C}_{i, j}^{\prime} / 8$. The other statistics are calculated as the simple average of the eight regressions.

\begin{tabular}{|c|c|c|c|c|c|c|c|c|c|}
\hline & Asia & EMEA & LatAm & GEM & Japan & Pacific & US & WE & Globe \\
\hline$\Gamma_{i, t}$ & $\begin{array}{r}-0.248 \\
0.442\end{array}$ & $\begin{array}{l}0.456 \\
0.087\end{array}$ & $\begin{array}{l}0.338 \\
0.245\end{array}$ & $\begin{array}{r}-0.044 \\
0.178\end{array}$ & $\begin{array}{r}-0.605 \\
0.330\end{array}$ & $\begin{array}{r}-0.066 \\
0.643\end{array}$ & $\begin{array}{l}-0.789 \\
-1.187\end{array}$ & $\begin{array}{r}0.316 \\
-0.473\end{array}$ & $\begin{array}{l}-0.254 \\
-0.569\end{array}$ \\
\hline$\Gamma_{i, t} D_{\text {Crisis }}$ & $\begin{array}{r}11.877 \\
4.983\end{array}$ & $\begin{array}{r}10.191 \\
5.010\end{array}$ & $\begin{array}{r}12.885 \\
4.504\end{array}$ & $\begin{array}{r}12.341 \\
5.681\end{array}$ & $\begin{array}{r}13.420 \\
5.772\end{array}$ & $\begin{array}{r}11.110 \\
6.543\end{array}$ & $\begin{array}{l}3.645 \\
4.962\end{array}$ & $\begin{array}{r}10.238 \\
7.007\end{array}$ & $\begin{array}{l}7.167 \\
5.188\end{array}$ \\
\hline$D_{\text {Crisis }}$ & $\begin{array}{r}3.245 \\
10.506\end{array}$ & $\begin{array}{r}3.581 \\
12.525\end{array}$ & $\begin{array}{r}3.548 \\
10.492\end{array}$ & $\begin{array}{l}2.433 \\
9.197\end{array}$ & $\begin{array}{l}1.415 \\
5.108\end{array}$ & $\begin{array}{r}2.288 \\
10.367\end{array}$ & $\begin{array}{l}1.920 \\
9.816\end{array}$ & $\begin{array}{r}2.408 \\
11.672\end{array}$ & $\begin{array}{r}2.065 \\
10.214\end{array}$ \\
\hline Constant & $\begin{array}{r}8.042 \\
53.028\end{array}$ & $\begin{array}{l}10.049 \\
66.170\end{array}$ & $\begin{array}{l}11.147 \\
65.193\end{array}$ & $\begin{array}{r}7.796 \\
57.526\end{array}$ & $\begin{array}{l}10.550 \\
78.178\end{array}$ & $\begin{array}{r}7.390 \\
64.608\end{array}$ & $\begin{array}{r}6.133 \\
62.318\end{array}$ & $\begin{array}{r}6.938 \\
63.976\end{array}$ & $\begin{array}{r}6.555 \\
64.702\end{array}$ \\
\hline $\begin{array}{l}N \\
R^{2} \\
\text { Adj. } R^{2}\end{array}$ & $\begin{array}{r}380 \\
0.475 \\
0.471\end{array}$ & $\begin{array}{r}381 \\
0.547 \\
0.544\end{array}$ & $\begin{array}{r}381 \\
0.551 \\
0.548\end{array}$ & $\begin{array}{r}384 \\
0.503 \\
0.499\end{array}$ & $\begin{array}{r}381 \\
0.385 \\
0.380\end{array}$ & $\begin{array}{l}391 \\
0.485 \\
0.482\end{array}$ & $\begin{array}{l}380 \\
0.498 \\
0.493\end{array}$ & $\begin{array}{l}380 \\
0.548 \\
0.544\end{array}$ & $\begin{array}{r}380 \\
0.521 \\
0.517\end{array}$ \\
\hline
\end{tabular}




\begin{tabular}{|c|c|c|c|c|c|c|c|c|c|}
\hline & Asia & EMEA & LatAm & GEM & Japan & Pacific & US & WE & Globe \\
\hline Asia & 11.27 & 12.18 & 10.96 & 1.08 & 1.75 & -6.14 & 66.24 & -4.18 & 13.14 \\
\hline EMEA & 19.20 & 14.07 & 11.49 & -.41 & 4.40 & -10.83 & 48.16 & -3.69 & 13.20 \\
\hline LatAm & 25.87 & 15.66 & 7.38 & .42 & 5.24 & -14.41 & 68.08 & -9.65 & 11.86 \\
\hline GEM & 19.23 & 11.59 & 7.54 & -1.49 & 2.29 & -7.47 & 55.74 & .43 & 9.39 \\
\hline Japan & 6.70 & 11.01 & 7.47 & -.07 & 1.79 & -7.86 & 78.70 & -.33 & 11.73 \\
\hline Pacific & 8.94 & 13.34 & 7.80 & 1.26 & 1.44 & -1.09 & 53.95 & -4.72 & 6.87 \\
\hline US & 5.68 & 9.11 & 8.02 & 2.52 & 2.87 & -4.24 & 30.50 & -1.95 & 7.15 \\
\hline WE & 8.55 & 12.48 & 8.32 & -.50 & 1.68 & -3.47 & 43.68 & .03 & 11.16 \\
\hline Globe & 11.04 & 10.08 & 5.28 & .59 & 2.23 & -4.68 & 33.17 & -.38 & 4.80 \\
\hline
\end{tabular}

Fig. 9. Coefficients of the interaction term of the granular residual and the crisis dummy. The diagonal cells report $\lambda_{i}^{\prime}$ from the regression of $\mathrm{VaR}_{i, t}=C_{i}+\lambda_{i} \Gamma_{i, t}+\lambda_{i}^{\prime} \Gamma_{i, t} D_{\text {Crisis }}+e_{i}$, while the off-diagonal cells report $\lambda_{j i i}^{\prime}$ from the regression of $\mathrm{CoVaR}_{j, t \mid i, t}=C_{j \mid i}+C_{j \mid i}^{\prime} D_{\text {Crisis }}+\lambda_{j \mid i} \Gamma_{i, t}+\lambda_{j \mid i}^{\prime} \Gamma_{i, t} D_{\text {Crisis }}+e_{j \mid i}$, where $j$ corresponds to the market specified in the leftmost column and $i$ refers to the market specified in the top row.

$$
\operatorname{CoVaR}_{j, t \mid i, t}=C_{j \mid i}+\lambda_{j \mid i, 1} \Gamma_{i, t-1}+\lambda_{j \mid i, 2} \Gamma_{i, t-2}+e_{j \mid i}
$$

The adjusted $R^{2}$ from regressions (8) and (9) are reported in Fig. 11. The lagged granular residuals have predictive power over the market risk fluctuations, as shown by the adjusted $R^{2}$. Notably, the lagged granular residuals of Pacific predict about 36\% of the variance of LatAm's risk conditional on Pacific being in distress. Conversely, the granular residuals of LatAm are associated with $21 \%$ of variations in Pacific. The predictive power of the granular residuals of GEM and WE is relatively

\begin{tabular}{|c|c|c|c|c|c|c|c|c|c|}
\hline & Asia & EMEA & LatAm & GEM & Japan & Pacific & US & WE & Globe \\
\hline Asia & .12 & .24 & . 10 & .02 & .05 & .00 & .13 & .07 & .06 \\
\hline EMEA & .17 & .20 & .03 & .01 & .35 & .03 & .14 & .14 & .17 \\
\hline LatAm & .10 & .09 & .03 & .01 & .38 & .09 & .14 & .10 & .10 \\
\hline GEM & .18 & .11 & .05 & .01 & .08 & .00 & .11 & .16 & .08 \\
\hline Japan & . 10 & .05 & .09 & .03 & .43 & .01 & .37 & .20 & .23 \\
\hline Pacific & .20 & .09 & .11 & .04 & .29 & .01 & .24 & .09 & .01 \\
\hline US & .30 & .02 & .05 & .09 & .45 & .13 & .12 & .15 & .09 \\
\hline WE & .18 & .12 & .18 & .02 & .11 & .07 & .22 & .21 & .26 \\
\hline Globe & .18 & .04 & .11 & .02 & .39 & .04 & .16 & .18 & .09 \\
\hline
\end{tabular}

Fig. 10. The adjusted $R^{2}$ based on an alternative measure of the granular residual. The granular residual is calculated using the 10 largest funds instead of the $10 \%$ largest funds. Based on the crisis subsample, each diagonal cell (row $i$ column $i$ ) reports the adjusted $R^{2}$ from the regression of $\mathrm{VaR}_{i, t}=C_{i}+\lambda_{i} \Gamma_{i, t}+e_{i}$, while each off-diagonal cell (row $j$ column $i$ ) reports the adjusted $R^{2}$ from the regression of $\operatorname{CoVaR}_{j, t \mid i, t}=C_{j \mid i}+\lambda_{j \mid i} \Gamma_{i, t}+e_{j \mid i}$. 


\begin{tabular}{|c|c|c|c|c|c|c|c|c|c|}
\hline & Asia & EMEA & LatAm & GEM & Japan & Pacific & US & WE & Globe \\
\hline Asia & .04 & .24 & .17 & .01 & .08 & .17 & .28 & .00 & .19 \\
\hline EMEA & .21 & .20 & .14 & .03 & .07 & .29 & .29 & .00 & .22 \\
\hline LatAm & .30 & .24 & .08 & .03 & .18 & .36 & .26 & .00 & .20 \\
\hline GEM & .16 & .33 & .12 & .03 & .03 & .21 & .27 & .00 & .18 \\
\hline Japan & .00 & .26 & .25 & .01 & .07 & .15 & .25 & .04 & .14 \\
\hline Pacific & .07 & .27 & .21 & .02 & .05 & .11 & .33 & .00 & .18 \\
\hline US & .10 & .28 & .20 & .01 & .17 & . 27 & .31 & .00 & .26 \\
\hline WE & .05 & .23 & .14 & .05 & .07 & .15 & .28 & .01 & .24 \\
\hline Globe & .18 & .24 & .21 & .02 & .12 & .25 & .30 & .00 & .23 \\
\hline
\end{tabular}

Fig. 11. The predictive power of the granular residuals. The diagonal cell in column $i$ reports the adjusted $R^{2}$ from the regression of $\mathrm{VaR}_{i, t}=C_{i}+\lambda_{i, 1} \Gamma_{i, t-1}+\lambda_{i, 2} \Gamma_{i, t-2}+e_{i}$, while the off-diagonal cell in row $j$ and column $i$ reports adjusted $R^{2}$ from the regression of $\mathrm{CoVaR}_{j, t \mid i, t}=C_{j \mid i}+\lambda_{j \mid i, 1} \Gamma_{i, t-1}+\lambda_{j \mid i, 2} \Gamma_{i, t-2}+e_{j \mid i}$.

small, most likely due to an aggregation issue. The evidence therefore is supportive that the granular residuals are useful predictor of the aggregate market risk and the cross-market interdependence.

\subsection{The granular effect and asset diversification}

The granular residuals explain a nontrivial fraction of the fluctuations in aggregate market risk as well as cross market interdependence. The degree of explanatory power however changes across markets and over time. There is some mild evidence that granular effect is stronger in less diversified market. We observe that the most concentrated market, Globe, with $67 \%$ of its TNA managed by the top $10 \%$ largest funds (see Table 2), turns out to have the highest average $R^{2}$ in the regression of CoVaR (Panel B of Table 3). To explore potential source of time variations in the granular effect, we study the role of the power law distribution of fund size, a proxy of the asset concentration with higher exponent corresponding to higher degree of concentration (see Naldi, 2003).

We first analyze the distribution of the mutual funds. For each week, we estimate the power law exponent, $\varsigma_{t}$, of the top $10 \%$ largest funds in our sample:

$$
P\left(\mathrm{TNA}_{t}^{i}>x\right) \sim x^{-\varsigma_{t}} .
$$

As shown in Fig. 12, the power law exponent escalates before the financial crisis and slide persistently after the financial crisis. The average value of $s_{t}$ is 1.58 in the crisis period (the shaded area in Fig. 12), compared to 1.51 in the noncrisis period. During the financial crisis when market is more concentrated, the explanatory power of the granular residual is larger (see Fig. 8). This supports the argument that lower degree of diversification is associated with stronger granular effect.

\section{Market interdependence and asset diversification}

We have earlier shown that emerging market tends to be riskier and more sensitive to risk transmission than developed market (see Fig. 1 and Table 1). This section explores whether the asset diversification is driving such difference. 


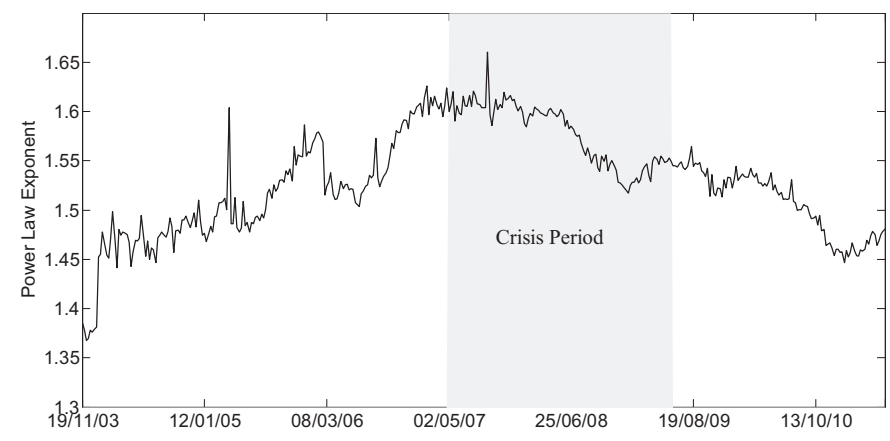

Fig. 12. The time-varying power law exponent of the TNA of the top $10 \%$ largest funds. The power law exponent $\varsigma_{t}$ is estimated every week based on $P\left(\mathrm{TNA}_{i, t}>x\right) \sim x^{-\varsigma_{t}}$, with $i$ being one of the top $10 \%$ largest funds.

We apply the power law exponent to measure the degree of asset diversification following Naldi (2003). For each week $t$, the power law exponent is estimated based on $P\left(\operatorname{TNA}_{i, t}^{k}>x\right) \sim x^{-\varsigma_{i, t}}$ for each market $i$, where $\mathrm{TNA}_{i, t}^{k}$ is the total net asset under management of fund $k$ investing in market $i$ at period $t$. The summary statistics of the estimated power law exponents are presented in Table 5. It turns out that exponents of emerging markets are generally higher than that of the developed markets, which suggest less diversification in emerging markets. To explore whether low degree of diversification is driving high risk and risk sensitivity, for each market, we run regressions of VaR and CoVaR on the time-varying power-law exponents. The estimated coefficients of the exponent are generally significant, with the value presented in Fig. 13. Except for exponents of GEM, Japan and Globe, where the funds tend to play the role of rebalancing, the coefficients of the exponents are generally positive. The result provide evidence that lower diversification is associated with higher aggregate market risk and stronger sensitivity to the external risk.

\section{Conclusion and discussion}

This paper finds evidence in support of the granular hypothesis in the context of equity fund investment. The idiosyncratic shocks to the granular institutional investors are found to explain a reasonably large fraction of the volatility of the aggregate market risk and the global market risk interdependence. Common risk factors, such as changes in global funding and market liquidity, risk appetite, are nevertheless important driving forces of global market interdependence. They however only account for $12 \%$ of the aggregate market risk fluctuations and $13 \%$ of the variance in global market risk interdependence. Including the granular residuals substantially increase these two numbers to $27 \%$ and $28 \%$ respectively. It suggests that idiosyncratic shocks to granular institutional investors could be an important and potentially major origin of the global market interdependence. The explanatory power of granular institutional investors on aggregate market risk and global market interdependence is significantly stronger during the period of the global financial crisis of 2007-09. These results are robust after controlling for common risk factors and

Table 5

Summary statistics of power law exponent. Each week $t$, the power law exponent is estimated based on $P\left(\operatorname{TNA}_{i, t}^{k}>x\right) \sim x^{-\varsigma_{i, t}}$ for each market $i$, where TNA $A_{i, t}^{k}$ is the total net asset under management of fund $k$ investing in market $i$ at period $t$. This table reports the summary statistics of the time-varying exponent for the nine markets.

\begin{tabular}{lcccccccrr}
\hline & Asia & EMEA & LatAm & GEM & Japan & Pacific & US & WE & Globe \\
\hline Mean & 1.537 & 1.756 & 2.118 & 1.065 & 1.096 & 1.313 & 1.559 & 1.658 & 1.328 \\
S.d & 0.349 & 0.590 & 3.226 & 0.121 & 0.102 & 0.278 & 0.082 & 0.113 & 0.111 \\
Min & 1.243 & 1.266 & 0.805 & 0.799 & 0.871 & 0.815 & 1.400 & 1.461 & 0.578 \\
Max & 2.339 & 3.975 & 29.948 & 1.759 & 2.264 & 2.189 & 1.769 & 2.417 & 1.515 \\
$N$ & 395 & 394 & 394 & 366 & 394 & 310 & 395 & 395 & 395 \\
\hline
\end{tabular}




\begin{tabular}{|c|c|c|c|c|c|c|c|c|c|}
\hline & Asia & EMEA & LatAm & GEM & Japan & Pacific & US & WE & Globe \\
\hline Asia & 1.66 & 3.14 & 4.83 & 3.54 & 1.30 & 1.80 & 1.53 & 1.70 & 2.30 \\
\hline EMEA & .50 & .12 & .11 & .47 & .15 & .24 & .11 & .10 & .03 \\
\hline LatAm & .12 & .07 & .06 & .08 & .08 & .09 & .05 & .09 & .07 \\
\hline GEM & -10.33 & -13.46 & -13.06 & -8.76 & -5.12 & -7.55 & -5.74 & -12.38 & -7.62 \\
\hline Japan & -2.51 & -5.01 & -3.56 & -2.69 & -2.15 & -2.11 & -2.77 & -3.15 & -2.28 \\
\hline Pacific & .49 & -.92 & -1.47 & .50 & 1.35 & .75 & -.52 & .63 & -.04 \\
\hline US & 9.69 & 5.00 & 11.49 & 8.68 & 14.38 & 9.70 & 5.99 & 5.33 & 5.35 \\
\hline WE & 6.27 & 6.93 & 7.18 & 9.54 & 5.09 & 3.28 & 4.60 & 3.83 & 5.32 \\
\hline Globe & -3.51 & -1.51 & -2.81 & -2.62 & -3.25 & -2.37 & -2.20 & -4.52 & -1.89 \\
\hline
\end{tabular}

Fig. 13. The estimated coefficients of power law exponent. The diagonal cell in column $i$ reports the estimated coefficient of the exponent from the regression of $\mathrm{VaR}_{i, t}=C_{i}+\beta_{i} \varsigma_{i, t}+e_{i}$, while the off-diagonal cell in row $j$ and column $i$ reports adjusted $R^{2}$ from the regression of $\mathrm{CoVaR}_{j, t \mid i, t}=C_{j \mid i}+\beta_{j \mid i} \varsigma_{i, t}+e_{j \mid i}$.

applying alternative measures of granular residuals, a measure of idiosyncratic shocks to large institutional investors.

This paper offers new evidence on financial interdependencies in the crisis of the 2007-09, and possible implications for understanding capital market instability. Idiosyncratic shocks to granular institutional investors are found to generate economically significant shocks to the aggregate market risk and account for an important fraction of fluctuations in global market interdependence. As provokingly discussed in the Economist (2013):

"Central bankers should take note. ... taking account of firm-specific shocks can help improve economic forecasts. The models that determine economywide decisions - like those run by the Federal Reserve ... - might be improved by looking at how big firms are doing."

The Economist, June 22nd, 2013.

Our empirical findings suggest that market information derived from proper monitoring of institutional investors can help understand not only the aggregate market risk but also the cross-market risk interdependence. This is especially true during periods of financial calamity. We believe that our findings are consistent with several channels of global risk transmission in the financial markets. In the context of our evidence, the transmission is possible through fire sales by distress funds holding common assets, market sentiment driven by fund flows, and active portfolio management transmitting shocks across markets, among others. The implication is that the market risk and volatility can also be transmitted not only across national markets but also across different types of financial institutions, including banks, insurance firms, hedge funds, thereby justifying the importance of on-going debates over 'too-big-to-fail' concern.

Subject to data availability, we would like to take on further analysis that crosscuts major financial investors and institutions in the future. As our results on equity investment were derived from a large number of countries, they suggest that such granular-investor driven too-big-to-fail concerns may apply globally. The distressful adjustment in the global capital markets in the aftermath of the crisis of 2007-2009, and the importance of granular effects recently brought to light in our study and elsewhere, calls for more policy-oriented analyses that can help minimize negative risk transmission across countries. 


\section{Appendix}

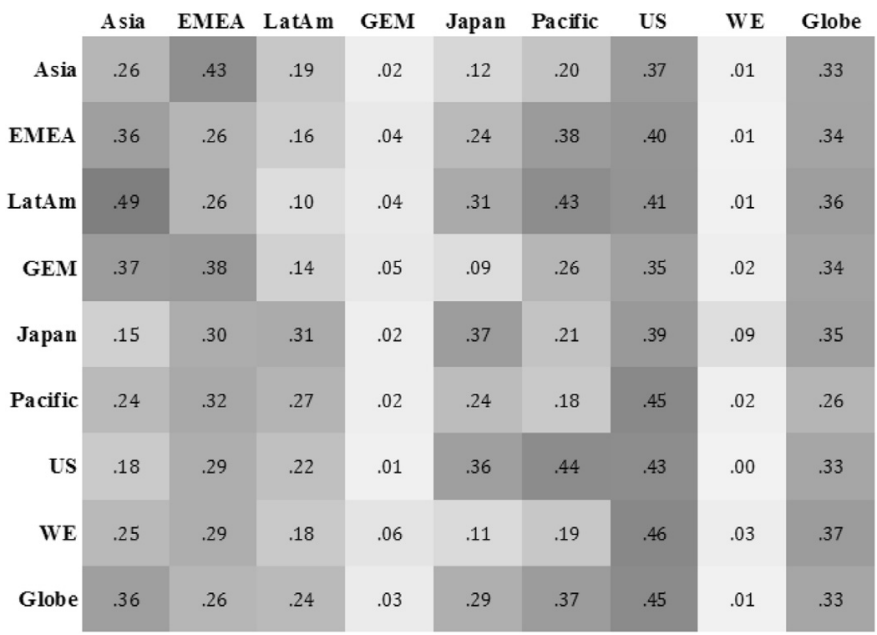

Appendix Fig. 1. The adjusted $R^{2}$ with 2 lags of granular residuals. The diagonal cell in column $i$ reports the adjusted $R^{2}$ from the regression of $\mathrm{VaR}_{i, t}=C_{i}+\lambda_{i, 0} \Gamma_{i, t}+\lambda_{i, 1} \Gamma_{i, t-1}+\lambda_{i, 2} \Gamma_{i, t-2}+e_{i}$, while the off-diagonal cell in row $j$ and column $i$ reports adjusted $R^{2}$ from the regression of $\operatorname{CoVaR}_{j, t \mid i, t}=C_{j \mid i}+\lambda_{j \mid i, 0} \Gamma_{i, t}+\lambda_{j \mid i, 1} \Gamma_{i, t-1}+\lambda_{j \mid i, 2} \Gamma_{i, t-2}+e_{j \mid i}$.

\section{Appendix Table 1}

Classification of regional markets.

\begin{tabular}{|c|c|c|}
\hline Region & Descriptions & Covering countries \\
\hline Asia & Asia ex-Japan & $\begin{array}{l}\text { China, Hong Kong, India, Indonesia, South } \\
\text { Korea, Malaysia, Philippines, Singapore, } \\
\text { Taiwan, Thailand, Vietnam }\end{array}$ \\
\hline EMEA & Europe, the Middle East and Africa & $\begin{array}{l}\text { Czech Republic, Egypt, Israel, Kuwait, } \\
\text { Poland, Qatar, Russia, Saudi Arabia, South } \\
\text { Africa, Turkey, United Arab Emirate }\end{array}$ \\
\hline LatAm & Latin America & $\begin{array}{l}\text { Argentina, Brazil, Chile, Colombia, Mexico, } \\
\text { Peru }\end{array}$ \\
\hline $\begin{array}{l}\text { GEM } \\
\text { Japan }\end{array}$ & $\begin{array}{l}\text { Global Emerging Market } \\
\text { Japan }\end{array}$ & $\begin{array}{l}\text { All countries in Asia, EMEA and LatAm } \\
\text { Japan }\end{array}$ \\
\hline Pacific & Pacific & Australia, New Zealand \\
\hline US & US & US \\
\hline WE & Western Europe & $\begin{array}{l}\text { Austria, Belgium, Denmark, Finland, France, } \\
\text { Germany, Greece, Italy, Netherlands, } \\
\text { Norway, Portugal, Spain, Sweden, } \\
\text { Switzerland, United Kingdom }\end{array}$ \\
\hline Globe & Globe & All countries in Japan, Pacific, US and WE \\
\hline
\end{tabular}

\section{References}

Adams, Z., Füss, R., Gropp, R., 2010. Modeling Spillover Effects Among Financial Institutions: a State-dependent Sensitivity Value-at-risk (SDSVaR) Approach. European Business School Research Paper No. 10-12.

Adrian, T., Brunnermeier, M.K., 2011. CoVaR. FRB of New York Staff Report No. 348.

Bekaert, G., Hodrick, R.J., Zhang, X., 2012. Aggregate idiosyncratic volatility. J. Financ. Quant. Anal. 47 (6), 1155-1185.

Bernanke, Ben S., Kuttner, Kenneth N., 2005. What Explains the Stock Market's Reaction to Federal Reserve Policy? J. Finan. 60 (3), 1540-6261.

Blank, S., Buch, C.M., Neugebauer, K., 2009. Shocks at large banks and banking sector distress: the banking granular residual. J. Financ. Stab. 5, 353-373.

Broner, F.A., Gaston Gelos, R., Reinhart, C.M., 2006. When in peril, retrench: testing the portfolio channel of contagion. J. Int. Econ. 69, 203-230.

Buch, C.M., Neugebauer, K., 2011. Bank-specific shocks and the real economy. J. Bank. Finance 35, 2179-2187.

Calvo, G.A., Mendoza, E.G., 2000. Rational contagion and the globalization of securities markets. J. Int. Econ. 51, 79-113.

Claessens, S., Forbes, K., 2001. International Financial Contagion. Kluwer Academic Publishers, Boston. 
Collin-Dufresne, P., Goldstein, R.S., Helwege, J., 2010. Is Credit Event Risk Priced? Modeling Contagion via the Updating of Beliefs. National Bureau of Economic Research Working Paper Series No. 15733.

Coval, J., Stafford, E., 2007. Asset fire sales (and purchases) in equity markets. J. Financ. Econ. 86 (2), 479-512.

Engle, R.F., Manganelli, S., 2004. CAViaR: conditional autoregressive value at risk by regression quantiles. J. Bus. Econ. Stat. 22, 367-381.

Forbes, K.J., Rigobon, R., 2002. No contagion, only interdependence: measuring stock market comovements. J. Finance 57, $2223-$ 2261.

Froot, K.A., O'Connell, P.G.J., Seasholes, M.S., 2001. The portfolio flows of international investors. J. Financ. Econ. 59, 151-193.

Gabaix, X., 2011. The granular origins of aggregate fluctuations. Econometrica 79, 733-772.

Gauthier, C., Lehar, A., Souissi, M., 2010. Macroprudential Capital Requirements and Systemic Risk. Available at SSRN: http:// ssrn.com/abstract $=1663993$.

Gelos, R.G., 2011. International Mutual Funds, Capital Flow Volatility, and Contagion - a Survey. IMF Working Papers, pp. 1-27. Available at SSRN: http://ssrn.com/abstract=1826545.

Giesecke, K., 2004. Correlated default with incomplete information. J. Bank. Finance 28, 1521-1545.

Giovanni, J.D., Levchenko, A.A., 2011. Country Size, International Trade, and Aggregate Fluctuations in Granular Economies. National Bureau of Economic Research Working Paper Series No. 17335.

Hamilton, J.D., 2008. Understanding the TED Spread.

Hamilton, J.D., Susmel, R., 1994. Autoregressive conditional heteroskedasticity and changes in regime. J. Econ. 64, 307-333.

Huang, X., Zhou, H., Zhu, H., 2012. Assessing the systemic risk of a heterogeneous portfolio of banks during the recent financial crisis. J. Financ. Stab. 8, 193-205.

Jinjarak, Y., Wongswan, J., Zheng, H., 2011. International fund investment and local market returns. J. Bank. Finance 35, $572-587$.

Jinjarak, Y., Zheng, H., 2012. On the Systemic Risk of Mutual Funds. Unpublished Working Paper 2012. The Institute of Global Economics and Finance, The Chinese University of Hong Kong.

Jotikasthira, C., Lundblad, C., Ramadorai, T., 2012. Asset fire sales and purchases and the international transmission of funding shocks. J. Finance 67, 2015-2050.

Koenker, R., Bassett, G., 1978. Regression quantiles. Econometrica 46 (1), 33-50.

Longin, F., Solnik, B., 2001. Extreme correlation of international equity markets. J. Finance 56, 649-676.

López-Espinosa, G., Moreno, A., Rubia, A., Valderrama, L., 2012. Short-term wholesale funding and systemic risk: a global CoVaR approach. J. Bank. Finance 36, 3150-3162.

Naldi, M., 2003. Concentration indices and Zipf's law. Econ. Lett. 78 (3), 329-334.

Raddatz, C., Schmukler, S.L., 2012. On the international transmission of shocks: micro-evidence from mutual fund portfolios. J. Int. Econ. 88, 357-374.

Stein, J.C., 2009. Presidential address: sophisticated investors and market efficiency. J. Finance 64, 1517-1548.

Wong, A.Y.T., Fong, T.P.W., 2011. Analysing interconnectivity among economies. Emerg. Mark. Rev. 12, 432-434. 